\title{
KATEUSZ, ALLY. (2019). MARY AND EARLY CHRISTLAN WOMEN: HIDDEN LEADERSHIP. NEW YORK: PALGRAVE MACMILLAN, 295 PP.
}

\author{
ERIC E. RichteR ${ }^{I}$ (D)
}

Ally Kateusz es profesora de historia eclesiástica en la Universidad de Missouri e investigadora del controversial Winjgaards Institute for Catholic Research. Se ha especializado en el arte cristiano en la antigüedad y medievo temprano. Esta obra, su segundo libro, está dividida en ocho capítulos. Algunos consisten en artículos previamente publicados que han sido revisados y ampliados. Su tesis central radica en afirmar que María de Nazareth fue considerada una líder eclesiástica y litúrgica en el cristianismo primitivo, lo cual se ve reflejado en representaciones artísticas y literarias de la época. Ella también aborda las inevitables implicancias que la percepción de la figura de María, como líder, tuvo en el rol de la mujer en el cristianismo primitivo, específicamente en funciones de liderazgo, enseñanza y evangelización.

El primer capítulo establece un breve trasfondo del tema y describe la metodología a seguir, que consiste en un análisis redaccional (crítica de la redacción) de fuentes literarias cristianas y un estudio de las representaciones artísticas de María de Nazareth en posiciones de liderazgo eclesiástico y litúrgico.

El capítulo siguiente presenta una refutación al principio lectio brevior potior, que críticos textuales utilizan para favorecer textos más cortos como los originales en detrimento de las recensiones más extensas. En contraste, Ally Kateusz argumenta que la omisión o supresión es más común que la interpolación. Es decir, copistas posteriores eran más propensos a omitir y quitar aquellos pasajes que consideraban heréticos, ofensivos o contrarios a la opinión teológica de su tiempo. Por lo tanto, cuanto más extensa sea una recensión, más probable es que sea la más antigua. La autora ejemplifica este principio utilizando diferentes manuscritos de la Dormición de la Virgen (Dormition of the Virgin), donde muestra que los más extensos describen a la Virgen María bautizando, predicando, dirigiendo una eucaristía, exorcizando demonios y capacitando a otras mujeres como evangelistas. Las recensiones más cortas, de manuscritos posteriores, suelen eliminar o "suavizar" estas declaraciones, minimizando así el rol autoritativo de María. El capítulo seis aplica la misma metodología a la Vida de la Virgen, una biografía de María de Nazareth atribuida a Máximo el Confesor.

1 Estudiante en la Facultad de Teología en la Universidad Adventista del Plata, Libertador San Martín, Entre Ríos, Argentina. Director asociado de la Revista bíblico-teológica Memrah. Correo electrónico: eric.richter@uap.edu.ar 
El capítulo tres muestra que el mismo proceso que minimizó o suprimió estas descripciones de la Virgen María también afectó los relatos de otras cuatro mujeres consideradas “apóstoles” en el cristianismo primitivo: Irene de Macedonia, Nino, Tecla y Mariamna. Pasajes que describían a estas mujeres bautizando, predicando, realizando milagros y siendo ordenadas al ministerio son alterados, eliminados o reemplazados en recensiones posteriores. En ocasiones, la autora sugiere, el cambio se realizó de una manera tan torpe que dejó evidentes contradicciones en los relatos.

Los capítulos cuatro y cinco se enfocan mayormente en las representaciones artísticas de la Virgen María en frescos, mosaicos, monedas y otros artefactos. Primero, Ally Kateusz expone algunas obras de literatura que describen a María de Nazareth oficiando la eucaristía, predicando y liderando a los apóstoles. Luego muestra una extensa galería de representaciones artísticas que ejemplifica la influencia que estos relatos tuvieron sobre el arte cristiano. Algunos de los gráficos presentan a María de Nazareth con ropas sacerdotales o episcopales, mientras que en otros se la ubica en un plano artístico de igualdad con su hijo Jesús. El capítulo siete enseña descripciones literarias y artísticas de otras mujeres del cristianismo primitivo como líderes eclesiásticas. Finalmente, el capítulo ocho despliega las reflexiones finales de la autora.

El libro de Ally Kateusz de la evidencia histórica primaria sobre roles femeninos de liderazgo en la iglesia apostólica, indudablemente representa un aporte al estudio del rol de la mujer en el cristianismo primitivo. Continúa la línea de Ute E. Eisen (2000), Carmen Bernabé Ubieta (1994; 2007), Karen Jo Torgesen (1993), Kevin Madigan y Carolyn Osiek (2005). Las noventa y dos páginas de notas y referencias bibliográficas demuestran la profundidad de la investigación.

No obstante, es posible señalar algunas observaciones al trabajo de Ally Kateusz. En ocasiones, su manera de expresarse suele ser rústica y repetitiva, además de que es posible encontrar algunos errores tipográficos en el texto. Esto hace pensar que el libro debió haber necesitado de un editor más atento. Más importante, sin embargo, es su consideración de fuentes históriográficas. A lo largo de su libro, la autora utiliza obras apócrifas cristianas ignorando su carácter pseudoepigráfico. Aunque pocos eruditos se atreverían a sugerir que estos libros no incluyen reminiscencias de tradiciones y memorias históricamente fidedignas, difícilmente aceptarían que estas obras son históricamente confiables, que reflejan con certeza la realidad del cristianismo apostólico o que realmente fueron escritos por los personajes a los que se les atribuyen. Aunque las obras apócrifas cristianas proporcionan información válida y útil acerca de las creencias y prácticas de sectas gnósticas y grupos heterodoxos, difícilmente pueden ser consideradas memorias históricas fiables del cristianismo apostólico.

En conclusión, Kateusz ha contribuido con un significativo aporte a la historia del arte cristiano y al rol de la mujer en el cristianismo primitivo. A pesar de algunas falencias en su libro, no deja de ser una lectura necesaria para cualquier persona interesada en estos temas. En un mundo marcado por el movimiento \#MeToo y "Ni una menos", este libro aborda las profundas implicancias que nuestra comprensión del cristianismo de los apóstoles puede tener en la sociedad contemporánea. Tal vez la relevancia de esta obra en la actualidad puede resumirse con la siguiente frase, que se encuentra en la conclusión del libro: "Ninguna iglesia puede excluir a mujeres de su liderazgo y permanecer fiel a sus orígenes". 
Reseña. Kateusz, Ally. (2019). Mary and Early Christian Women: Hidden Leadership. New York: Palgrave Macmillan, 295 pp.

\section{Referencias}

Bernabé Ubieta, C. (1994). María Magdalena: Tradiciones en el cristianismo primitivo. Estela: Verbo Divino.

Bernabé Ubieta, . (2007). Mujeres con autoridad en el cristianismo primitivo. Estella: Verbo Divino.

Eisen, U. E. (2000). Women Officeholders in Early Christianity: Epigraphical and Literary Studies. Collegeville, MN: The Liturgical Press.

Madigan, K. \& Osiek, C. (2005). Ordained Women in the Early Church: A Documentary History. Baltimore, MD: The Johns Hopkins University Press.

Torgesen, K. J. (1993). When Women Were Priest: Women's Leadership in the Early Church and the Scandal of Their Subordination in the Rise of Christianity. San Francisco, CA: Harper. 